\title{
Real-time PCR applications for diagnosis of leishmaniasis
}

\author{
Luca Galluzzi ${ }^{*} \mathbb{D}$, Marcello Ceccarelli, Aurora Diotallevi, Michele Menotta and Mauro Magnani
}

\begin{abstract}
Leishmaniasis is a vector-borne disease caused by many Leishmania species, which can infect both humans and other mammals. Leishmaniasis is a complex disease, with heterogeneous clinical manifestations ranging from asymptomatic infections to lesions at cutaneous sites (cutaneous leishmaniasis), mucosal sites (mucocutaneous leishmaniasis) or in visceral organs (visceral leishmaniasis), depending on the species and host characteristics. Often, symptoms are inconclusive and leishmaniasis can be confused with other co-endemic diseases. Moreover, co-infections (mainly with HIV in humans) can produce atypical clinical presentations. A correct diagnosis is crucial to apply the appropriate treatment and the use of molecular techniques in diagnosis of leishmaniasis has become increasingly relevant due to their remarkable sensitivity, specificity and possible application to a variety of clinical samples. Among them, real-time PCR (qPCR)-based approaches have become increasingly popular in the last years not only for detection and quantification of Leishmania species but also for species identification. However, despite qPCR-based methods having proven to be very effective in the diagnosis of leishmaniasis, a standardized method does not exist. This review summarizes the qPCR-based methods in the diagnosis of leishmaniasis focusing on the recent developments and applications in this field.
\end{abstract}

Keywords: HRM, Leishmania, Leishmaniasis, Melting curve analysis, Molecular diagnosis, GPCR, Real-time PCR

\section{Background}

Leishmaniasis is caused by protozoan parasites of the genus Leishmania. This genus includes three subgenera: Leishmania, Viannia and Sauroleishmania. Each subgenus presents different complexes and each complex includes several species [1]. Depending on the Leishmania species and host characteristics, the infection can be asymptomatic or it can lead to a spectrum of diseases, notably cutaneous leishmaniasis (CL), visceral leishmaniasis (VL) or mucocutaneous leishmaniasis (MCL). About 12 million people are affected by the disease; moreover, $0.2-0.4$ million cases per year and 0.7-1.2 million cases per year have been estimated for VL and for CL, respectively [2]. Infections are widespread both in the Americas (New World) and in Europe, Africa, Asia (Old World), therefore constituting an important global health problem.

The diagnosis of leishmaniasis relies on clinical manifestations, epidemiological and laboratory data. Concerning the laboratory methods, a gold-standard for human

\footnotetext{
* Correspondence: luca.galluzzi@uniurb.it

Department of Biomolecular Sciences, University of Urbino Carlo Bo, via Saffi 2, 61029 Urbino, PU, Italy
}

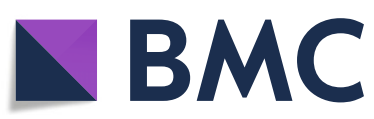

(C) The Author(s). 2018 Open Access This article is distributed under the terms of the Creative Commons Attribution 4.0 International License (http://creativecommons.org/licenses/by/4.0/), which permits unrestricted use, distribution, and

reproduction in any medium, provided you give appropriate credit to the original author(s) and the source, provide a link to the Creative Commons license, and indicate if changes were made. The Creative Commons Public Domain Dedication waiver (http://creativecommons.org/publicdomain/zero/1.0/) applies to the data made available in this article, unless otherwise stated.

patients or animals is lacking [3], impairing accurate epidemiological data collection and thus limiting the disease control. Moreover, false-negative results could delay treatment, thus contributing to reservoirs maintenance. Several immunological and molecular diagnostic tools for diagnosis of leishmaniasis have been developed recently [4]. In particular, the use of molecular techniques has become increasingly relevant due to their high sensitivity, specificity and possible application to a variety of clinical samples. Among them, the real-time PCR, also named quantitative PCR (qPCR), has become increasingly popular recently since it is fast, has broad dynamic range, and cross-contamination is drastically reduced because there is no need to open reaction tubes for post-PCR analyses. The qPCR relies on analysis of fluorescent signal produced during amplification. Fluorescence can be generated by using intercalating fluorescent dyes (e.g. SYBR Green) or fluorescent probes (e.g. TaqMan'). The assays based on intercalating dyes are characterized by high sensitivity, as long as primers are highly specific to the target sequence to avoid generation of non-specific products that would lead to overestimated or false positive results. A 
melting curve analysis can be performed post-PCR to ensure the presence of a single specific amplicon. For genotyping purposes, high resolution melt (HRM) analysis can be used to differentiate amplicons based on sequence variations [5]. The use of probes is typically more expensive. However, using probes allows multiplexing (partially reducing the cost per assay) and furnish additional specificity to the assay. Therefore, this approach is less subject to false positives than the intercalating dye method.

A search in PubMed in February 2018 with the wildcard term "Leishmania" in conjunction with the search terms "real-time PCR or qPCR", found over 540 published manuscripts from 2001 to February 2018. A further combination with the wildcard terms "quantif" or "detect" or "diagnos" and a manual sift of the papers identified nearly 180 manuscripts focusing on the topic of this review. Nevertheless, many of these publications apply similar assays.

The pioneering works of Bretagne et al. [6] and Nicolas et al. [7] described two qPCR-based methods to detect and quantify Leishmania parasites using the DNA polymerase gene and the minicircles kinetoplast DNA (kDNA) as a target, respectively. Since then, a variety of qPCR-based assays have been developed on different molecular targets, not only for detection and quantification of Leishmania species but also for genotyping and species identification. Regarding the detection chemistry, SYBR Green and TaqMan ${ }^{\circ}$ probes were most widely employed, followed by other probes, such as FRET probes $[8,9]$ or MGB probes [10]. The sensitivity and specificity reported for published $\mathrm{qPCR}$ assays is variable. For instance, qPCR assays developed for VL diagnosis in humans showed a specificity variation between $29.6-100 \%$ and sensitivity between $91.3-100 \%$, indicating the usefulness of the qPCR when a sensitive tool is pivotal [4].

In this review, recent developments and applications of qPCR-based methods in the diagnosis of leishmaniasis are summarized, highlighting advances and limits of this powerful technique.

\section{Molecular targets}

Many qPCR-based approaches for the diagnosis of leishmaniasis have been published based on coding and/or non-coding regions in the Leishmania genome. Leishmania spp. have 34-36 chromosomes and a unique genomic organization in which protein-coding genes are organized in polycistronic units and do not have introns; moreover, gene expression is regulated post-transcriptionally (i.e. at the levels of mRNA stability and translation) [11]. Leishmania parasites also possess a mitochondrial genome called kinetoplast DNA, which is organized in thousands of minicircles $(0.8-1.0 \mathrm{~Kb}$ each) and several dozens of maxicircles (approximately $23 \mathrm{~Kb}$ each) linked in a concatenated network.

\section{Non-protein-coding regions}

The kDNA minicircles account for approximately 95\% of kDNA and encode small guide RNAs (gRNAs), needed for RNA-editing of the transcripts encoded by maxicircles [12]. Since minicircles are present in thousands of copies per cell, they are ideal targets for highly sensitive detection of Leishmania [13, 14]. Each minicircle is composed of a conserved region containing the origin of replication, and a variable region encoding usually a single gRNA [15]. The minicircle network is composed of different minicircle classes. Their number can be variable and dependent from strain; in a recent work, the presence of over 100 minicircles classes has been demonstrated in a strain of $L$. tarentolae using NGS technology [16].

The minicircle conserved region contains 3 conserved sequence blocks (CSB-1, CSB-2 and CSB-3) that could be effective targets for PCR amplification of all minicircle classes. However, polymorphisms have been shown in CSB-1 region of L. infantum [14] and, using primers amplifying a subpopulation of minicircles, also in CSB-2 region of New World species [17]. In general, the assays designed on minicircles conserved regions identify Leishmania parasites only at the genus or subgenus level. In fact, $\mathrm{qPCR}$ assays intended for a single species designed on minicircles can potentially amplify more than one Leishmania species, as shown by several authors [14, 18-22].

Among targets on chromosomal DNA, different regions of ribosomal RNA (rRNA) genes, termed ribosomal DNA (rDNA), have been used. Tens or hundreds of copies of rDNA unit can be present per Leishmania cell, allowing sufficient sensitivity for analyzing clinical sample DNA [23, 24]. Each rDNA repeat unit consists of several genes and spacers: the SSU rRNA gene (18S) is followed by $5.8 S$ and $L S U$ genes; two internal transcribed spacer regions -ITS1 and ITS2 - are located between the $18 S$ and $5.8 S$ genes and between $5.8 S$ and $L S U \alpha$ genes, respectively [25]. The $18 S \mathrm{rDNA}$ region, due to its highly conserved nature, is commonly utilized to design primers and/or probes for the diagnosis of Leishmania spp. [26]. On the other hand, the ITS regions, which have more variable sequences, can be used for typing at the species level [24, 27, 28].

In principle, $\mathrm{qPCR}$ assays designed on minicircles kDNA conserved regions allow to reach the highest limit of detection, due to their high number per parasite. In fact, a detection limit of $5 \times 10^{-4}$ parasites per PCR reaction tube, with a dynamic range of $10^{7}$, has been reported for L. infantum, allowing to detect up to 0.0125 parasites/ml of blood [18]. In general, the sensitivity limit depends on assay design (which target region is 
selected), chemistry used (intercalating dyes or fluorescent probes), the nature of clinical sample and the DNA extraction method. For instance, Gomes et al. [22] compared the sensitivity of two qPCR assays (based on SYBR Green or TaqMan probe) targeting Leishmania (Viannia) kDNA using swabs and biopsy samples from MCL and CL patients. The authors showed that sensitivity did not vary significantly by sample type, but rather according to the method: the SYBR green-based assay reached the higher level of sensitivity. It is also important to emphasize that the observed higher sensitivity of SYBR green might reflect differences in DNA sequences at primer annealing sites, rather than the qPCR chemistry itself.

\section{Protein-coding sequences}

Many protein coding genes have also been used as target in qPCR assays for identification/quantification of the parasites. Among them are the Heat Shock Protein $70 \mathrm{kDa}$ (HSP70) [20, 27, 29, 30], DNA polymerase [6, 20, 31-34], glucose-6-phosphate dehydrogenase $(G 6 P D)[13,35]$, glucose phosphate isomerase (GPI) [36], mannose phosphate isomerase $(M P I)$, 6-phosphogluconate dehydrogenase (6PGD) [9], tryparedoxin peroxidase [37], etc. These targets have in general high specificity but lower sensitivity compared to targets with high copy numbers, such as kDNA minicircles or rDNA. HSP7O could be considered an exception, since it is a multicopy gene [38]. In fact, an optimized qPCR assay showed a limit of detection of 0.1 parasites/ml of culture [30]. HSP70 gene has been widely used for Leishmania phylogenetic studies [39] and its sequence heterogeneity has been implemented in several PCR-RFLP approaches [40] and qPCR-based typing methods (see below). The G6PD, MPI, GPI and 6PGD genes encode for enzymes used in multi-locus enzyme electrophoresis (MLEE) analysis and were also used in multi-locus sequence typing (MLST) approaches [41]. The limit of detection of qPCR assays designed on single copy genes can be high (e.g. 5.6 pg parasite DNA per reaction) [36]. In other cases (using DNA polymerase or G6PD as target) the limit of detection has been reported in 0.4 parasites/reaction [32] and 10 target copies/reaction [13].

\section{Clinical samples}

To establish a qPCR-based method for diagnosis of leishmaniasis, other than selection of target sequence (size, genetic stability, copy number, level of specificity) and characterization of assay performance (specificity, sensitivity, accuracy and reproducibility), it is essential to test the assay with clinical samples.

The correct sampling is often critical for success of downstream test [42]; in fact, clinical samples can be heterogeneous, depending on clinical presentation $(\mathrm{CL}, \mathrm{VL}$,
MCL). For CL, nucleic acids can be extracted from a fullthickness skin biopsy specimen collected from a lesion, while for MCL, biopsy specimens should be collected from mucosal areas with abnormalities [43]. Also swabs from $\mathrm{CL}$ or MCL lesions are emerging as a powerful diagnostic tool because of its non-invasive and simple collection method [22, 44]. For VL, bone marrow or lymph-node aspirates, as well as whole blood or buffy coat, are common source of tissue samples [43]. Recently, the detection of $L$. infantum $\mathrm{kDNA}$ by qPCR was also demonstrated in urine of untreated individuals affected by VL. The fact that parasite's DNA was not found after start of therapy indicated that urine could be considered a potential alternative specimen to follow up the efficacy of therapeutic approaches [45]. The presence of L. infantum kDNA in urine was also shown in dogs with natural clinical leishmaniasis, although in lower amounts compared to blood or bone marrow [46]. In canine or feline leishmaniasis (CanL or FeL), conjunctival swabs have shown to be a valid alternative to other more invasive clinical samples, such as blood, bone marrow or lymph-node aspirates $[34,47-50]$. Also nasal, oral or ear swabs have been successfully tested $[33,51]$.

Real-time PCR has been used to explore the presence of Leishmania DNA in tissues of wild mammals both in New World and Old World, to find potential parasite reservoirs. For example, Leishmania DNA was found from rodent and bat spleen tissues [52-55]. Furthermore, $L$. infantum DNA has been also retrieved from hair of wild mammals, such as Leporidae [56], fox, wolf, rat, marten and hedgehog [57].

All clinical samples require the use of an internal reference (generally a host sequence, e.g. $\beta$-actin or beta-2-microglobulin), not only to monitor PCR inhibition (i.e. false-negative results), but also to normalize the parasite load to the amount of host cells $[33,34,48,58]$. Although some clinical samples may contain a small amount of parasite DNA, the use of high copy number sequence as targets (e.g. kDNA minicircle, rDNA) can ensure adequate sensitivity.

\section{qPCR assays for parasite detection and quantification}

As outlined above, numerous quantitative and qualitative real-time PCR-based assays to be used in veterinary or human medicine have been published recently, targeting different genetic markers and for application to different types of samples [51, 59-69]. The main features of qPCR assays targeting $\mathrm{kDNA}, \mathrm{rDNA}$ or other DNA regions are summarized in Table 1, Table 2 and Table 3, respectively.

Several assays developed for the diagnosis of leishmaniasis report only qualitative results (i.e. positive or negative detection) [22, 70]. These qualitative assays exploit 
Table 1 Summary of the characteristics of real-time PCR assays targeting Leishmania kDNA, in chronological order

\begin{tabular}{|c|c|c|c|c|c|}
\hline Geographical region & Type of sample & Assay type & Assay chemistry & Typing & Reference \\
\hline Old World & Mouse tissues & Quantitative & Intercalating dye & No & {$[7]$} \\
\hline Old World & Parasite cultures & Qualitative & Intercalating dye & Yes & {$[96]$} \\
\hline Old World & Blood/ bone marrow & Quantitative & Fluorescent probe & No & [18] \\
\hline Old World & Blood/ lymph node/skin & Quantitative & Fluorescent probe & No & {$[65]$} \\
\hline Old World & Blood/ lymph node/skin & Quantitative & Fluorescent probe & No & {$[67]$} \\
\hline Old World & Blood/ bone marrow & Quantitative & Fluorescent probe & No & {$[80]$} \\
\hline Old World & Urine/ blood/ bone marrow & Quantitative & Fluorescent probe & No & {$[46]$} \\
\hline Old World & skin lesions & Qualitative & Intercalating dye & Yes & {$[97]$} \\
\hline New World & blood & Quantitative & Intercalating dye & No & {$[106]$} \\
\hline Old World & Blood/ bone marrow & Quantitative & Fluorescent probe & No & [3] \\
\hline New World & Bone marrow & Qualitative & $\begin{array}{l}\text { Intercalating dye/ Fluorescent } \\
\text { probe }\end{array}$ & No & {$[62]$} \\
\hline $\begin{array}{l}\text { Old World/ New } \\
\text { World }\end{array}$ & Blood/ skin biopsy & Quantitative & $\begin{array}{l}\text { Intercalating dye/ Fluorescent } \\
\text { probe }\end{array}$ & Yes & {$[20]$} \\
\hline New World & Sand flies & Quantitative & Intercalating dye & No & {$[32]$} \\
\hline Old World & Blood & Qualitative & Intercalating dye & No & {$[70]$} \\
\hline Old World & Ticks & Quantitative & Fluorescent probe & No & {$[94]$} \\
\hline Old World & $\begin{array}{l}\text { Blood/ lymph node/ Oral swab/ Conjunctival } \\
\text { swab }\end{array}$ & Quantitative & Fluorescent probe & No & {$[50]$} \\
\hline Old World & Blood/ ticks & Quantitative & Fluorescent probe & No & [93] \\
\hline New World & Blood/ bone marrow/ skin biopsy/ sand flies & Qualitative & Intercalating dye & Yes & [98] \\
\hline Old World & Blood/ bone marrow & Quantitative & Fluorescent probe & No & {$[61]$} \\
\hline New World & Blood/ skin biopsy & Quantitative & Intercalating dye & Yes & [59] \\
\hline New World & Skin biopsy & Quantitative & Intercalating dye & No & {$[13]$} \\
\hline Old World & $\begin{array}{l}\text { Blood/ lymph nodes/ bone marrow/ } \\
\text { conjunctival swab }\end{array}$ & Qualitative & Intercalating dye & No & {$[64]$} \\
\hline Old World & Blood/ lymph node/ dog hairs & Quantitative & Fluorescent probe & No & {$[63]$} \\
\hline New World & $\begin{array}{l}\text { Blood /bone marrow/ skin biopsy/ } \\
\text { conjunctival swab }\end{array}$ & Qualitative & Intercalating dye & No & [49] \\
\hline $\begin{array}{l}\text { Old World/ New } \\
\text { World }\end{array}$ & Blood/ conjunctival swab & Quantitative & Intercalating dye & Yes & {$[14,48]$} \\
\hline New World & Sand flies & Qualitative & Intercalating dye & No & {$[88]$} \\
\hline New World & Skin biopsy/ scraping/ cytology brushes & Quantitative & Intercalating dye & No & {$[78]$} \\
\hline $\begin{array}{l}\text { Old World/ New } \\
\text { World }\end{array}$ & Liver & Quantitative & Fluorescent probe & No & [19] \\
\hline New World & $\begin{array}{l}\text { Oral swabs/ conjunctival swab/ blood/ } \\
\text { lymph node }\end{array}$ & Quantitative & Intercalating dye & No & {$[51]$} \\
\hline New World & Blood & Qualitative & Intercalating dye & Yes & [99] \\
\hline New World & Skin & Quantitative & Intercalating dye & No & {$[107]$} \\
\hline New World & Blood/ urine & Quantitative & Intercalating dye & No & {$[45]$} \\
\hline New World & Lesion swab/ biopsy & Qualitative & $\begin{array}{l}\text { Intercalating dye/ Fluorescent } \\
\text { probe }\end{array}$ & Yes & {$[22]$} \\
\hline Old World & Sand flies & Qualitative & Intercalating dye & No & {$[92]$} \\
\hline $\begin{array}{l}\text { Old World/ New } \\
\text { World }\end{array}$ & Blood/ conjunctival swab & Quantitative & Intercalating dye & Yes & {$[17]$} \\
\hline Old World & Sand flies & Quantitative & Intercalating dye & No & {$[87]$} \\
\hline New World & Parasite cultures & Quantitative & Intercalating dye & No & {$[30]$} \\
\hline New World & Blood & Quantitative & Fluorescent probe & No & {$[81]$} \\
\hline
\end{tabular}


Table 1 Summary of the characteristics of real-time PCR assays targeting Leishmania kDNA, in chronological order (Continued)

\begin{tabular}{|c|c|c|c|c|c|}
\hline Geographical region & Type of sample & Assay type & Assay chemistry & Typing & Reference \\
\hline New World & Blood/splenic aspirate/skin & Quantitative & Fluorescent probe & No & [82] \\
\hline New World & Cerebrospinal fluid/ CNS tissues/ spleen & Quantitative & Fluorescent probe & No & [108] \\
\hline New World & Lymph node/ bone marrow & Quantitative & Intercalating dye & $\begin{array}{l}\text { Specific for } L . \\
\text { infantum }\end{array}$ & [109] \\
\hline
\end{tabular}

the advantages of real-time technology to reduce the time of analysis and the risk of contamination. Moreover, many of these assays were often finalized to obtain genotyping information (see below) $[8,71]$.

Other assays were developed to estimate the parasite load through absolute or relative quantification. The absolute quantification relies on the use of a standard curve, obtained with serial dilutions of purified parasite genomic DNA or target sequence. The use of high-copy $18 S$ and minicircle kDNA sequences as a target usually allows amplification at the genus or subgenus level, due to their conserved sequences or to the heterogeneity of minicircle classes [72]. The reliability of quantification results is dependent on (i) the knowledge of the target sequence copy number/ cell, and (ii) the fact that this number does not vary significantly among species or between the reference and field strains. Concerning minicircle kDNA, their copy number can vary between $L$. (Leishmania) species or between isolates within a single species [18, 20], potentially affecting the quantification accuracy of qPCR assays. However, no statistically significant differences in the relative number of kDNA minicircle targets among three L. (Viannia) species were found [13]. Moreover, the minicircle kDNA copy number within the same strain or in amastigotes infecting a single patient during a survey appears stable; therefore, a qPCR assay designed on this target can be used to compare parasitemia levels during the survey of the patient, and can be particularly useful for relapse monitoring [18]. Changes in minicircle copy numbers during stage transition (promastigotes-amastigotes) has also been investigated in a $L$. chagasi strain (L. chagasi has been shown to be identical to L. infantum from southwest Europe [73]). No significant differences were found, concluding that standard

Table 2 Summary of the characteristics of real-time PCR assays targeting Leishmania rDNA, in chronological order

\begin{tabular}{|c|c|c|c|c|c|}
\hline Geographical region & Type of sample & Assay type & Assay chemistry & Typing & Reference \\
\hline Old World & Blood & Quantitative & Fluorescent probe & No & [26] \\
\hline Old World/ New World & Blood/ bone marrow/ skin biopsy & Quantitative & Fluorescent probe & Yes & [101] \\
\hline New World & Cell cultures & Quantitative & Intercalating dye & No & {$[110]$} \\
\hline New World & Skin biopsy & Quantitative & Fluorescent probe & No & [111] \\
\hline Old World & Mouse skin biopsy & Quantitative & Fluorescent probe & No & [112] \\
\hline Old World & Bone marrow & Quantitative & Intercalating dye & No & [113] \\
\hline Old World & $\begin{array}{l}\text { Smears from cutaneous lesions/ blood/ } \\
\text { skin or spleen biopsy }\end{array}$ & Quantitative & Intercalating dye & Yes & [28] \\
\hline New World & Sand flies & Quantitative & Intercalating dye & No & [32] \\
\hline New World & Blood/skin biopsy & Quantitative & Intercalating dye & Yes & [59] \\
\hline Old World & $\begin{array}{l}\text { Blood/ bone marrow/ lymph node/ } \\
\text { cutaneous lesion aspirates }\end{array}$ & Qualitative & Fluorescent probe & Yes & [71] \\
\hline Old World & Fixed lymph node biopsy & Quantitative & Fluorescent probe & Specific for L. tropica & [114] \\
\hline New World & Swab/ lesion aspirates & Quantitative & Fluorescent probe & No & [44] \\
\hline New World & Parasite cultures & Qualitative & Intercalating dye & Yes & {$[27]$} \\
\hline Old World & Blood/ bone marrow & Quantitative & Intercalating dye & Yes & [102] \\
\hline Old World & Fixed skin biopsy & Quantitative & Fluorescent probe & No & {$[115]$} \\
\hline New World & Ticks & Qualitative & Intercalating dye & No & [95] \\
\hline Old World/ New World & Blood/ skin biopsy/ bone marrow & Qualitative & Intercalating dye & Yes & {$[58]$} \\
\hline Old World & Sand flies & Qualitative & Fluorescent probe & Yes & [92] \\
\hline New World & Skin biopsy & Quantitative & Intercalating dye & No & [76] \\
\hline New World & Parasite cultures & Quantitative & Intercalating dye & No & [30] \\
\hline
\end{tabular}


Table 3 Summary of the characteristics of real-time PCR assays targeting Leishmania sequences other than kDNA or rDNA, in chronological order

\begin{tabular}{|c|c|c|c|c|c|c|}
\hline Target sequence & $\begin{array}{l}\text { Geographical } \\
\text { region }\end{array}$ & Type of sample & Assay type & $\begin{array}{l}\text { Assay } \\
\text { chemistry }\end{array}$ & Typing & Reference \\
\hline DNA pol & Old World & Liver biopsy & Quantitative & $\begin{array}{l}\text { Fluorescent } \\
\text { probe }\end{array}$ & No & [6] \\
\hline GPI & $\begin{array}{l}\text { Old World/ } \\
\text { New World }\end{array}$ & Skin biopsy & Qualitative & $\begin{array}{l}\text { Fluorescent } \\
\text { probe }\end{array}$ & Yes & [36] \\
\hline DNA pol & New World & Sand flies & Quantitative & $\begin{array}{l}\text { Fluorescent } \\
\text { probe }\end{array}$ & No & [85] \\
\hline GP63 & Old World & Mice tissues & Quantitative & Intercalating dye & Yes & [68] \\
\hline G6PD & New World & Biopsy & Quantitative & $\begin{array}{l}\text { Intercalating } \\
\text { dye/ Fluorescent } \\
\text { probe }\end{array}$ & Yes & [35] \\
\hline DNA pol & New World & Sand flies & Quantitative & Intercalating dye & No & [32] \\
\hline $\begin{array}{l}\text { Alpha-tubulin, DNA pol, Spliced leader, } \\
\text { MSP-associated gene (MAG), SIDER repeat, } \\
\text { GPI, HSP70, splice leader-associated } \\
\text { retrotransposons (SLACS) }\end{array}$ & $\begin{array}{l}\text { Old World/ } \\
\text { New World }\end{array}$ & Blood/ skin biopsy & Quantitative & $\begin{array}{l}\text { Intercalating } \\
\text { dye/ Fluorescent } \\
\text { probe }\end{array}$ & Yes & [20] \\
\hline tryparedoxin peroxidase & Old World & Skin biopsy & Qualitative & Intercalating dye & Yes & [37] \\
\hline DNA pol & New World & $\begin{array}{l}\text { Skin biopsy/ bone } \\
\text { marrow/ blood/ } \\
\text { conjunctival swab }\end{array}$ & Quantitative & $\begin{array}{l}\text { Fluorescent } \\
\text { probe }\end{array}$ & No & [34] \\
\hline DNA pol & New World & $\begin{array}{l}\text { Bone marrow/ skin } \\
\text { biopsy/ nasal, oral, } \\
\text { ear swab }\end{array}$ & Quantitative & $\begin{array}{l}\text { Fluorescent } \\
\text { probe }\end{array}$ & No & [33] \\
\hline$M P I, 6 P G D$ & New World & Scrapings/ skin biopsy & Qualitative & $\begin{array}{l}\text { Fluorescent } \\
\text { probe }\end{array}$ & Yes & [9] \\
\hline G6PD & New World & Biopsy & Quantitative & Intercalating dye & No & [13] \\
\hline HSP7O & New World & Parasite cultures & Qualitative & Intercalating dye & Yes & [27] \\
\hline$A A P 3$ & $\begin{array}{l}\text { Old World/ } \\
\text { New World }\end{array}$ & Mouse tissues & Quantitative & $\begin{array}{l}\text { Fluorescent } \\
\text { probe }\end{array}$ & No & [116] \\
\hline REPL repeats (L42486.1) & Old World & Blood & Quantitative & $\begin{array}{l}\text { Fluorescent } \\
\text { probe }\end{array}$ & $\begin{array}{l}\text { Specific for } L \text {. } \\
\text { infantum and } L \text {. } \\
\text { donovani }\end{array}$ & [117] \\
\hline LinJ31 & $\begin{array}{l}\text { Old World/ } \\
\text { New World }\end{array}$ & $\begin{array}{l}\text { Lymph node/ bone } \\
\text { marrow aspirate/ tissue } \\
\text { samples }\end{array}$ & Quantitative & $\begin{array}{l}\text { Fluorescent } \\
\text { probe }\end{array}$ & $\begin{array}{l}\text { Specific for } \\
\text { subgenus } \\
\text { Leishmania }\end{array}$ & [118] \\
\hline$C P B$ & Old World & Cutaneous biopsy & Qualitative & $\begin{array}{l}\text { Fluorescent } \\
\text { probe }\end{array}$ & Yes & [8] \\
\hline HSP70 & $\begin{array}{l}\text { Old World/ } \\
\text { New World }\end{array}$ & Biopsy/ sand flies & Qualitative & Intercalating dye & Yes & [29] \\
\hline IPPP, RNase III & New World & Sand flies & Quantitative & Intercalating dye & Yes & [119] \\
\hline REPL repeats (L42486.1) & Old World & Blood/ skin & Quantitative & $\begin{array}{l}\text { Fluorescent } \\
\text { probe }\end{array}$ & $\begin{array}{l}\text { Specific for } L \text {. } \\
\text { infantum and } L \text {. } \\
\text { donovani }\end{array}$ & [69] \\
\hline HSP7O & New World & Parasite cultures & Quantitative & Intercalating dye & No & [30] \\
\hline
\end{tabular}

curves generated from promastigote-derived DNA can be used for quantification of amastigotes of the same species/strain [20].

It is also noteworthy that minicircle sequence heterogeneity could be lost during continuous culturing [74]; also, it has been shown that in vitro selection of drug-resistant $L$. amazonensis lead to changes in kDNA minicircle class dominance [75]. Single-copy targets do not present these drawbacks and could lead to better quantitative accuracy, but their sensitivities can be too low for diagnostic purposes using samples with low parasite loads and without parasite isolation/cultivation. For example, the single copy gene DNA polymerase I has been used to normalize minicircle kDNA copy numbers using the comparative quantification $(\Delta \Delta \mathrm{Ct})$ method $[18,20]$. 
When using clinical samples, the presence of host DNA as background should be taken into account. In fact, excess of background DNA could affect the reliability of qPCR results. Therefore, standard curves should be tested by adding appropriate amounts of host DNA into PCR mixtures to mimic amplification in clinical samples. In some cases, the presence of background DNA may affect $\mathrm{Ct}$ values: delays of several cycles were observed in qPCR assays targeting minicircle kDNA using Leishmania DNA samples spiked with human or canine DNA (100 ng and $30 \mathrm{ng}$, respectively) [14, 17]. Nevertheless, the linearity range of qPCR remained unchanged up to the assay detection limits. In other cases, the background host DNA did not appear to affect the $\mathrm{Ct}$ values. For example, in a qPCR targeting G6PD, similar $\mathrm{Ct}$ values were obtained in the presence versus absence of human DNA (20 ng) and sensitivity was not affected by the presence of this background DNA [13]. We also tested the use of conjunctival swabs (CS) for the evaluation of CanL by qPCR targeting kDNA. Since we used raw CS lysates as source of Leishmania DNA, their potential inhibition in qPCR was tested: it was found that $1 \mu \mathrm{l}$ raw lysate per $25 \mu \mathrm{l}$ qPCR reaction mixture did not show any inhibitory effect on the assays, allowing accurate quantification [48].

While using blood as clinical sample gives results as parasites $/ \mathrm{ml}$, the quantification on solid samples (swabs, biopsies, etc.) requires the quantification of both parasites and the host cells (by means of another qPCR for a single copy host gene). The comparison of the two qPCR results allows to obtain the number of parasites/number of host cells [13, 33, 34, 48, 76, 77]. Alternatively, if yield of DNA extraction is reproducible among different samples and the amount of DNA can be accurately determined, the number of parasites could also be normalized to $\mu \mathrm{g}$ of tissue DNA [78]. In addition to the parasite and host cell quantification, a $\Delta \mathrm{Ct}$ value between amplification curves of the Leishmania target and a host reference gene (Ct Leishmania - Ct host gene) was used as an additional parameter to monitor parasite load changes during the course of the illness or treatment. In fact, increases or decreases in $\Delta \mathrm{Ct}$ values correlate with decreases or increases in parasite loads, respectively $[48,79]$. This comparison is possible only if qPCR efficiencies of Leishmania and host gene are similar. This approach, based on $\Delta \mathrm{Ct}$ calculation of two qPCR assays, could get around the problem of exact parasite load quantification (based on standard reference strains) and could avoid the use of two standard curves, therefore limiting the cost of assays [48].

Recently, efforts have been made to reduce cost and time necessary to obtain diagnostic results, as well as to decrease manipulation steps, therefore reducing the risk of mistakes or contamination. For example, a real-time
PCR assay previously developed by Francino et al. [80] for the detection and quantification of $L$. infantum kinetoplast DNA, has been optimized in terms of lower reaction volume and shorter running time [81]. Moreover, Rampazzo et al. [82] developed a ready-to-use (gelified and freezer-free) duplex qPCR for the identification of $L$. infantum in dogs. In this assay, a qPCR for detection of the canine $18 S$ rRNA gene and a qPCR for L. infantum $\mathrm{kDNA}$ detection were combined, showing a detection limit of 1 parasite/reaction in all canine tissues tested (splenic aspirates, skin and blood).

The qPCR assays for leishmaniasis that amplify species-specific DNA sequences are not appropriate for regions with sympatric Leishmania species [83]. In fact, even in areas where Leishmania species are known, the presence of polymorphisms and variations in copy number of target sequences (e.g. minicircle classes), could interfere with the performance of qPCR assays. To rule out false negatives or co-infections with other Leishmania species, the species-specific qPCR should be combined with a genus-specific assay (broad range assay) [24]. Therefore, approaches based on initial amplification of genus-specific sequences followed by assays for species differentiation/typing should be useful.

\section{qPCR assays for Leishmania monitoring in insect vectors}

The arthropod vectors involved in the Leishmania transmission are only the phlebotomine sand flies, with 98 species of the genera Phlebotomus and Lutzomyia proven or suspected to be vectors of human leishmaniasis [84]. Since microscopic detection of parasites in sand fly guts is laborious and time-consuming, biomolecular assays were introduced with the aim to investigate the potential role of sand fly species in spreading Leishmania parasites. In 2008 Ranasinghe et al. [85] proposed a qPCR assay to detect $L$. chagasi DNA in Lutzomyia longipalpis, using the DNA polymerase gene of parasite as molecular target and a TaqMan ${ }^{\bullet}$ probe, with a detection limits of $10 \mathrm{pg}$ Leishmania DNA ( 120 parasites) in $100 \mathrm{ng}$ sand fly DNA. The quantification of parasite load in the vector can be very important. In fact, it is well known that Leishmania parasites can manipulate sand fly feeding behavior since a high parasite load in sand fly midguts is correlated to a persistent feeding pattern that leads to an increase in Leishmania transmission [86]. The principal mechanism proposed is the blockage of the stomodeal valve that forces sand flies to remain feeding for longer on the same or different hosts, obtaining often only a partial blood meal. This fact can increase the likelihood of parasite transmission [87]. Thus, considering the importance of a quantitative test, BezerraVasconcelos et al. investigated other molecular targets, with the aim of to improve the assay sensitivity [32]. In 
their work, the authors analyzed the sensitivity of kDNA, DNA polymerase $\alpha$ and $18 \mathrm{~S}$ rRNA gene in SYBR-Greenbased qPCR assays. The amplification of kDNA exhibited the greatest sensitivity, showing the capacity to detect DNA equivalent to 0.004 parasites, and the highest accuracy. Successively, Cunha et al. [88] investigated the use of kDNA qPCR versus kDNA conventional PCR for detection of L. infantum DNA in Lutzomyia longipalpis, concluding that kDNA qPCR can be used for epidemiological studies since this assay was particularly advantageous when analyzing samples containing a small number of parasites. In a similar approach, a kDNA SYBR-Green qPCR was used to study the outbreak in southwestern Madrid region. The use of a quantitative approach permitted the study of the parasite load in unfed and blood-fed Phlebotomus perniciosus female sand flies caught in the focus area. The data obtained allowed the authors to confirm that the high parasite load in females of $P$. perniciosus without blood in their guts is undeniable proof of a proper establishment and replication of the parasites in the sand fly midgut [87]. Using qPCR-based approaches, Leishmania DNA has also been detected in sand flies from Albania [89], Tunisia [90] and Turkey [91]. Recently, an interesting approach based on sequential qPCR targeting kDNA followed by ITS1 qPCR was proposed by Karaku et al. [92] to study a leishmaniasis focus in southwestern Turkey. In fact, in this region different Leishmania species coexist, therefore a genusspecific kDNA SYBR-Green qPCR was used to screen for infection in the collected sandflies and qPCR targeting ITS1 region was performed using species-specific primers for detecting $L$. donovani/infantum complex, $L$. tropica and L. major. Moreover, the DNA extracted from the abdomens of freshly blood-fed female sandflies was amplified using the cytochrome $b$ gene as a target to identify the vertebrate source of the blood meal and to reveal the host preferences in the study area [92]. Interestingly, the qPCR approach was utilized also to detect L. infantum DNA in ticks (Rhipicephalus sanguineus) removed from dogs living in endemic areas in Italy, finding the parasite DNA in a fraction of ticks examined [93, 94]. Successively, Leishmania spp. promastigotes were detected in the intestine, ovary and salivary glands of $R$. sanguineus actively infesting dogs in Brazil [95]. In the light of these evidences, additional studies will be needed to further explore the role of the ticks in Leishmania infection.

\section{qPCR assays for Leishmania genotyping}

Both qualitative and quantitative real-time PCR assays can be designed to gain information regarding parasite typing at the subgenus, complex, or species level. Different targets have been evaluated for this purpose, such as ITS region, SSU, HSP70, G6PD, 6PGD, MPI, cysteine protease B $(c p B)$, kDNA minicircle, etc. [83]. Various qPCR-based typing methods have been published in recent years. For example, Wortmann et al. developed real-time PCR assays for the detection and differentiation of four Leishmania complexes (L. mexicana, $L$. donovani/infantum, $L$. major and species belonging to the subgenus Viannia). The primers/probes were designed on the glucose phosphate isomerase (GPI) gene exploiting the sequence variability of this gene among Leishmania species. The limit of detection for all assays was $5.6 \mathrm{pg}$, equivalent to approximately 165 genome copies [36].

PCR primers that specifically amplify a species or a group of species have been designed on minicircle kDNA, exploiting sequence polymorphisms. However, several authors observed cross-reaction among species, probably because of minicircle classes variability in each of them [17, 19, 20, 23]. In a different approach, using common primers to amplify different species, differences in melting temperature (Tm) of PCR-amplified minicircle kDNA regions were exploited to differentiate Leishmania species. Nicolas et al. optimized an assay to distinguish the Old World species L. major, L. donovani, $L$. tropica and $L$. infantum. However, this assay could not differentiate $L$. tropica and L. infantum by their Tm values [96]. Successively, De Monbrison et al. [97] used the same primers in a real-time PCR followed by melting curve analysis to monitor Leishmania species in CL patients from Algeria, confirming prevalence of L. major (44.1\%). However, about 30\% of clinical samples were not determinable. In another study, the Tm analysis of amplicons generated from the conserved region of minicircle kDNA allowed the differentiation of the subgenus L. (Leishmania) from L. (Viannia), but species identification was not possible [98]. Successively, de Morais et al. [99] identified two Tm ranges using previously developed primers, designed on minicircle kDNA [59], to differentiate two groups of species causing $C L$ in Brazil. The group 1 included $L$. (V.) braziliensis, $L$. $(V$.) panamensis, L. $(V$.$) lainsoni, L .(V$.$) guyanensis, L$. (V.) shawi $\left(\mathrm{Tm}=78-79.99{ }^{\circ} \mathrm{C}\right)$, and the group 2 included $L .(V$.$) naiffi, L$. (L.) amazonensis and $L$. ( $L$.) mexicana $\left(\mathrm{Tm}=80-82.2^{\circ} \mathrm{C}\right)$. A total of 223 positive blood samples were analyzed by qPCR followed by $\mathrm{Tm}$ analysis, and the results were compared with other techniques such as SSU sequencing, kDNA PCR-RFLP and MLEE. No significant differences were found between $\mathrm{qPCR}$ and MLEE or SSU sequencing methods, while a highly significant difference was observed for qPCR and RFLP.

Approaches based on Tm analysis were also attempted using tryparedoxin peroxidase gene [37]. In this case, a SYBR-green based qPCR on tryparedoxin peroxidase gene incorporating a melting step analysis was developed 
to discriminate between $L$. (L.) major and $L$. (L.) tropica causing cutaneous leishmaniasis in Iran [37].

Melting analysis was also performed using fluorescence resonance energy transfer (FRET) probes [100]. First to apply this technology for Leishmania typing, Schulz et al. designed a qPCR assay with FRET probes using SSU region as target [101]. The assay showed analytical sensitivity of 94.1 parasites/ml blood (CI 95\%, 70-145.3 parasites $/ \mathrm{ml}$ ) and melting probes analysis distinguished three clinically relevant groups ( $L$. donovani complex, $L$. braziliensis complex, and other Leishmania spp.). More recently, Tsukayama et al. [9] exploited the polymorphisms in the genes MPI and 6PGD to design two real-time PCR assays based on FRET technology and melting curve analysis. These assays identified five Leishmania species of the Viannia subgenus highly prevalent in South America: $L .(V$. braziliensis, $L .(V$.$) panamensis, L .(V$.$) guyanensis, L .(V$. peruviana and $L$. $(V$.) lainsoni. However, to increase sensitivity of the assays with clinical samples, conventional PCRs for MPI and 6PGD genes were carried out prior to the nested real-time PCR amplifications, but this impaired the possibility of quantification. An approach based on FRET technology and melting curve analysis was also used by Nath-Chowdhury et al. [8] to differentiate Old World CL species $[L$. (L.) major, $L$. (L.) tropica, and $L .(L$.$) aethiopica],$ using the $c p B$ gene as target. Moreover, Toz et al. [71] developed a real-time PCR assay on ITS1 to identify the Old World species $L$. (L.) tropica, $L$. $(L$.) major and $L$. (L.) donovani complex, using FRET probes to diagnose and simultaneously differentiate among Turkish species in clinical samples. This assay provided sufficient sensitivity for fast and correct detection of parasites directly from clinical materials, allowing the identification of $L$. $(L$.) tropica and $L$. (L.) infantum as causative agents of human CL, VL and CanL in Turkey [71].

The introduction of high-resolution melt (HRM) technology allowed improved technical approaches for Leishmania species identification. The HRM analysis of an amplicon from ITS1 region was used to identify Old World Leishmania species [28]. When tested on 300 samples from human cases, reservoir hosts and sand flies, this approach distinguished $L$. major, L. tropica, $L$. aethiopica and $L$. infantum/donovani species. More recently, Cardoso et al. [102] used this assay to evaluate the epidemiological role of red foxes as reservoirs in Portugal. HRM analysis of amplicon from HSP7O gene allowed the discrimination of eight Leishmania New World species, i.e. $L$. (L.) chagasi, $L$. (L.) amazonensis, $L$. (L.) mexicana, $L .(V$.$) lainsoni, L .(V$.$) braziliensis, L .(V$. guyanensis, $L$. $(V$.) naiffi and $L$. $(V$.) shawi, and three Old World species, i.e. $L$. (L.) tropica, $L$. ( $L$.) donovani and $L$. (L.) major [29]. This method demonstrated high sensitivity, detecting less than one parasite per reaction, even in the presence of host DNA. In another approach, the sequential amplification and HRM analysis of HSP7O and then ITS1, allowed to discriminate six New World Leishmania species (L. mexicana, L. infantum chagasi, L. amazonensis, L. panamensis, L. guyanensis and L. braziliensis) with a detection limit of 10 parasites/ml [27]. HRM analysis has also been applied to minicircle kDNA qPCR, allowing discrimination between subgenera Leishmania and Viannia, and from $L$. (L.) infantum and $L$. (L.) amazonensis reference strains [14]. However, HRM analysis performed on 62 clinical specimens from dogs infected by $L$. (L.) infantum showed that discrimination between $L$. (L.) amazonensis and $L$. (L.) infantum was not possible in $53.4 \%$ of cases due to melting peak overlapping or late amplification $\left(\mathrm{Ct}^{>} \mathrm{30}\right)$ [17]. Therefore, a combination of two qPCR assays was used to distinguish $L$. (L.) infantum and $L$. (L.) amazonensis, exploiting the major abundance of a minicircle kDNA class in $L$. $(L$.) amazonensis rather than targeting a hypothetical species-specific sequence [17]. Importantly, in a systematic study, Weirather et al. [20] developed a serial qPCR strategy to identify and rapidly differentiate Leishmania species and quantify parasites. First, selected screening primers were used to recognize kinetoplast minicircle DNA of all Leishmania species. Then, further qPCRs individualized for geographical regions were employed for species identification, combining primers, probes and melt curve analysis. The combination of assays allowed detection, quantification and species determination of Leishmania parasites in different samples from patients from Bangladesh or Brazil, with different forms of leishmaniasis [20].

Taken together, real-time PCR based assays have demonstrated reliability and affordability in typing Leishmania spp. However, due to parasite variability/ heterogeneity, a single method to quantify parasites and determine the species in clinical specimens cannot be established and the need of combining different assays or adapt them to geographical regions has emerged.

\section{Conclusions}

The application of qPCR to the diagnosis of leishmaniasis has contributed to the development of sensitive and specific approaches which are important part of the diagnostic process and allow implementation of early and adequate treatment $[103,104]$. Real-time PCR applications for Leishmania species detection/quantification and typing represent an advance to classic methodologies in terms of automation and high throughput possibility, rapidity and high sensitivity. Nevertheless, a standardized assay to simultaneously estimate parasite load and genotype the species of interest in a particular geographical area is still lacking. In fact, no consensus exists concerning clinical sample harvesting procedures, DNA extraction methods, target sequences, use of host 
target as reference for normalization or as quality control, etc. Furthermore, due to heterogeneity of published qPCR-based assays and the fact that each assay has pros and cons, it is difficult to identify an ideal approach. Therefore, a combination of different assays can be proposed for maximizing sensitivity and specificity. Since the first goal of a clinical or epidemiological investigation is to determine the presence or absence of Leishmania parasites, a high-copy target ensuring low limit of detection, such as minicircle kDNA, appears the best choice. However, the sensitivity of qPCR targeting minicircle kDNA can vary in function of species, complex or subgenus (depending on minicircle classes composition). Therefore, dependent on species in a particular geographical area, different qPCR assays to detect different taxa with high sensitivity can be run in parallel or sequentially to obtain an indication of subgenus or complex (through melting analysis or relative abundance of target sequence), as well as quantitative information. Then, based on results obtained, other qPCR assays can be selected for genotyping at the species level. The use of SYBR green coupled to melting or HRM analysis will help to reduce cost but will not allow multiplexing. Moreover, in cases of clinical samples with low parasite content, a nested approach can be used to enrich the target sequence before the application of species-specific qPCR assays, therefore avoiding late amplification $\left(\mathrm{Ct}^{>} \mathrm{30}\right)$ or failure to reach a plateau, in order to limit inconclusive or lowreproducible results in HRM analysis [105]. Despite considerable progress made in recent years, real-time PCR is still far from the clinical routine application in endemic areas. The cost of equipment and reagents is an important factor that hinders the transition from research to routine clinical application in endemic areas. However, miniaturization of real-time PCR equipment, as well as increased affordability of $\mathrm{qPCR}$ reagents could increase the routine use of the qPCR approaches in low-income countries.

\section{Abbreviations \\ 6PGD: 6-phosphogluconate dehydrogenase; CL: Cutaneous leishmaniasis; Ct: Threshold cycle; FRET: Fluorescence resonance energy transfer; G6PD: Glucose-6-phosphate dehydrogenase; GPI: Glucose phosphate isomerase; HRM: High resolution melt; HSP70: Heat-shock protein 70; kDNA: Kinetoplast DNA; MCL: Mucocutaneous leishmaniasis; MPI: Mannose phosphate isomerase; qPCR: Quantitative real-time PCR; VL: Visceral leishmaniasis}

\section{Availability of data and materials}

Data sharing is not applicable to this article as no datasets were generated or analysed during the current study.

\section{Authors' contributions}

LG collected the literature information and wrote the first draft of the manuscript. $M C$ collected the literature information. $M C, A D, M M, M M$ critically revised the manuscript. All authors read and approved the final manuscript.

Ethics approval and consent to participate Not applicable.

\section{Competing interests}

The authors declare that they have no competing interests.

\section{Publisher's Note}

Springer Nature remains neutral with regard to jurisdictional claims in published maps and institutional affiliations.

Received: 28 February 2018 Accepted: 18 April 2018

Published online: 02 May 2018

\section{References}

1. Bates PA. Transmission of Leishmania metacyclic promastigotes by phlebotomine sand flies. Int J Parasitol. 2007:37:1097-106.

2. Alvar J, Vélez ID, Bern C, Herrero M, Desjeux P, Cano J, et al. Leishmaniasis worldwide and global estimates of its incidence. PLoS One. 2012;7:e35671.

3. Rodriguez-Cortes A, Ojeda A, Francino O, Lopez-Fuertes L, Timon M, Alberola J. Leishmania infection: laboratory diagnosing in the absence of a "gold standard". Am J Trop Med Hyg. 2010;82:251-6.

4. de Paiva-Cavalcanti M, de Morais RCS, Pessoa-e-Silva R, Trajano-Silva LAM, Gonçalves-de-Albuquerque S da C, Tavares D de HC, et al. Leishmaniases diagnosis: an update on the use of immunological and molecular tools. Cell Biosci. 2015;5:31.

5. Reed GH, Kent JO, Wittwer CT. High-resolution DNA melting analysis for simple and efficient molecular diagnostics. Pharmacogenomics. 2007;8:597-608.

6. Bretagne S, Durand R, Olivi M, Garin J-F, Sulahian A, Rivollet D, et al. Realtime PCR as a new tool for quantifying Leishmania infantum in liver in infected mice. Clin Vaccine Immunol. 2001;8:828-31.

7. Nicolas L, Prina E, Lang T, Milon G. Real-time PCR for detection and quantitation of Leishmania in mouse tissues. J Clin Microbiol. 2002;40:1666-9.

8. Nath-Chowdhury M, Sangaralingam M, Bastien P, Ravel C, Pratlong F, Mendez J, et al. Real-time PCR using FRET technology for Old World cutaneous leishmaniasis species differentiation. Parasit Vectors. 2016;9:255.

9. Tsukayama P, Núñez JH, De Los Santos M, Soberón V, Lucas CM, Matlashewski G, et al. A FRET-based real-time PCR assay to identify the main causal agents of New World tegumentary leishmaniasis. PLoS Negl Trop Dis. 2013;7:e1956.

10. Galletti E, Bonilauri P, Bardasi L, Fontana MC, Ramini M, Renzi M, et al. Development of a minor groove binding probe based real-time PCR for the diagnosis and quantification of Leishmania infantum in dog specimens. Res Vet Sci. 2011;91:243-5.

11. Llanes A, Restrepo CM, Vecchio GD, Anguizola FJ, Lleonart R. The genome of Leishmania panamensis: insights into genomics of the L. (Viannia) subgenus. Sci Rep. 2015;5:8550.

12. Stuart KD, Schnaufer A, Ernst NL, Panigrahi AK. Complex management: RNA editing in trypanosomes. Trends Biochem Sci. 2005;30:97-105.

13. Jara M, Adaui V, Valencia BM, Martinez D, Alba M, Castrillon C, et al. Realtime PCR assay for detection and quantification of Leishmania (Viannia) organisms in skin and mucosal lesions: exploratory study of parasite load and clinical parameters. J Clin Microbiol. 2013;51:1826-33.

14. Ceccarelli M, Galluzzi L, Migliazzo A, Magnani M. Detection and characterization of Leishmania (Leishmania) and Leishmania (Viannia) by SYBR green-based real-time PCR and high resolution melt analysis targeting kinetoplast minicircle DNA. PLoS One. 2014:9:e88845.

15. Sturm NR, Simpson L. Leishmania tarentolae minicircles of different sequence classes encode single guide RNAs located in the variable region approximately 150 bp from the conserved region. Nucleic Acids Res. 1991; 19:6277-81.

16. Simpson L, Douglass SM, Lake JA, Pellegrini M, Li F. Comparison of the mitochondrial genomes and steady state transcriptomes of two strains of the trypanosomatid parasite, Leishmania tarentolae. PLoS Negl Trop Dis. 2015;9:e0003841.

17. Ceccarelli M, Galluzzi L, Diotallevi A, Andreoni F, Fowler H, Petersen C, et al. The use of kDNA minicircle subclass relative abundance to differentiate between Leishmania (L.) infantum and Leishmania (L.) amazonensis. Parasit Vectors. 2017;10:239.

18. Mary C, Faraut F, Lascombe L, Dumon $\mathrm{H}$. Quantification of Leishmania infantum DNA by a real-time PCR assay with high sensitivity. J Clin Microbiol. 2004:42:5249-55.

19. Losada-Barragán M, Cavalcanti A, Umaña-Pérez A, Porrozzi R, Cuervo-Escobar S, Vallejo $\mathrm{AF}$, et al. Detection and quantification of Leishmania infantum in naturally and experimentally infected animal samples. Vet Parasitol. 2016;226:57-64. 
20. Weirather JL, Jeronimo SMB, Gautam S, Sundar S, Kang M, Kurtz MA, et al. Serial quantitative PCR assay for detection, species discrimination, and quantification of Leishmania spp. in human samples. J Clin Microbiol. 2011;49: 3892-904.

21. Miró G, Cardoso L, Pennisi MG, Oliva G, Baneth G. Canine leishmaniosis new concepts and insights on an expanding zoonosis: part two. Trends Parasitol. 2008;24:371-7.

22. Gomes CM, Cesetti MV, de Paula NA, Vernal S, Gupta G, Sampaio RNR, et al. Field validation of SYBR Green- and TaqMan-based real-time PCR using biopsy and swab samples to diagnose American tegumentary leishmaniasis in an area where Leishmania (Viannia) braziliensis is endemic. J Clin Microbiol. 2017;55:526-34.

23. Van der Auwera G, Dujardin J-C. Species typing in dermal leishmaniasis. Clin Microbiol Rev. 2015;28:265-94.

24. Schonian G, Kuhls K, Mauricio IL. Molecular approaches for a better understanding of the epidemiology and population genetics of Leishmania. Parasitology. 2011;138:405-25.

25. Martinez-Calvillo S, Sunkin SM, Yan S, Fox M, Stuart K, Myler PJ. Genomic organization and functional characterization of the Leishmania major Friedlin ribosomal RNA gene locus. Mol Biochem Parasitol. 2001;116:147-57.

26. Bossolasco S, Gaiera G, Olchini D, Gulletta M, Martello L, Bestetti A, et al. Realtime PCR assay for clinical management of human immunodeficiency virusinfected patients with visceral leishmaniasis. J Clin Microbiol. 2003;41:5080-4.

27. Hernández C, Alvarez C, González C, Ayala MS, León CM, Ramírez JD. Identification of six New World Leishmania species through the implementation of a High-Resolution Melting (HRM) genotyping assay. Parasit Vectors. 2014;7:501.

28. Talmi-Frank D, Nasereddin A, Schnur LF, Schönian G, Töz SÖ, Jaffe CL, et al. Detection and identification of Old World Leishmania by high resolution melt analysis. PLoS Negl Trop Dis. 2010;4:e581.

29. Zampieri RA, Laranjeira-Silva MF, Muxel SM, Stocco de Lima AC, Shaw J, Floeter-Winter LM. High resolution melting analysis targeting hsp70 as a fast and efficient method for the discrimination of Leishmania species. PLoS Negl Trop Dis. 2016;10:e0004485.

30. León CM, Muñoz M, Hernández C, Ayala MS, Flórez C, Teherán A, et al. Analytical performance of four polymerase chain reaction $(P C R)$ and real time PCR (qPCR) assays for the detection of six Leishmania species DNA in Colombia. Front Microbiol. 2017:8:1907.

31. Reis LES, Coura-Vital W, Roatt BM, LÉM B, Ker HG, Fortes de Brito RC, et al. Molecular diagnosis of canine visceral leishmaniasis: a comparative study of three methods using skin and spleen from dogs with natural Leishmania infantum infection. Vet Parasitol. 2013:197:498-503.

32. Bezerra-Vasconcelos DR, Melo LM, Albuquerque ÉS, Luciano MCS, Bevilaqua CML. Real-time PCR to assess the Leishmania load in Lutzomyia longipalpis sand flies: screening of target genes and assessment of quantitative methods. Exp Parasitol. 2011;129:234-9.

33. Ferreira S De A, Almeida GG, Silva S De O, Vogas GP, Fujiwara RT, De Andrade ASR, et al. Nasal, oral and ear swabs for canine visceral leishmaniasis diagnosis: new practical approaches for detection of Leishmania infantum DNA. PLoS Negl Trop Dis. 2013;7:e2150.

34. de Almeida Ferreira S, Leite RS, Ituassu LT, Almeida GG, Souza DM, Fujiwara RT, et al. Canine skin and conjunctival swab samples for the detection and quantification of Leishmania infantum DNA in an endemic urban area in Brazil. PLoS Negl Trop Dis. 2012;6:e1596.

35. Castilho TM, Camargo LMA, McMahon-Pratt D, Shaw JJ, Floeter-Winter LM. A real-time polymerase chain reaction assay for the identification and quantification of American Leishmania species on the basis of glucose-6phosphate dehydrogenase. Am J Trop Med Hyg. 2008;78:122-32.

36. Wortmann G, Hochberg L, Houng H-H, Sweeney C, Zapor M, Aronson N, et al. Rapid identification of Leishmania complexes by a real-time PCR assay. Am J Trop Med Hyg. 2005;73:999-1004.

37. Khosravi S, Hejazi SH, Hashemzadeh M, Eslami G, Darani HY. Molecular diagnosis of Old World leishmaniasis: real-time PCR based on tryparedoxin peroxidase gene for the detection and identification of Leishmania spp. J Vector Borne Dis. 2012;49:15-8.

38. Ramírez CA, Requena JM, Puerta CJ. Identification of the HSP70-II gene in Leishmania braziliensis HSP70 locus: genomic organization and UTRs characterization. Parasit Vectors. 2011:4:166.

39. Fraga J, Montalvo AM, De Doncker S, Dujardin J-C, Van der Auwera G. Phylogeny of Leishmania species based on the heat-shock protein 70 gene. Infect Genet Evol. 2010;10:238-45.
40. Montalvo AM, Fraga J, El Safi S, Gramiccia M, Jaffe CL, Dujardin J-C, et al. Direct Leishmania species typing in Old World clinical samples: evaluation of 3 sensitive methods based on the heat-shock protein 70 gene. Diagn Microbiol Infect Dis. 2014;80:35-9.

41. Zemanová E, Jirků M, Mauricio IL, Horák A, Miles MA, Lukeš J. The Leishmania donovani complex: genotypes of five metabolic enzymes (ICD, $\mathrm{ME}, \mathrm{MPI}, \mathrm{G} 6 \mathrm{PDH}$, and FH), new targets for multilocus sequence typing. Int J Parasitol. 2007;37:149-60.

42. Moreira OC, Yadon ZE, Cupolillo E. The applicability of real-time PCR in the diagnostic of cutaneous leishmaniasis and parasite quantification for clinical management: current status and perspectives. Acta Trop. 2017 https://doi.org/10.1016/j.actatropica.2017.09.020

43. Aronson N, Herwaldt BL, Libman M, Pearson R, Lopez-Velez R, Weina P, et al Diagnosis and treatment of leishmaniasis: clinical practice guidelines by the Infectious Diseases Society of America (IDSA) and the American Society of Tropical Medicine and Hygiene (ASTMH). Am J Trop Med Hyg. 2017;96:24-45.

44. Adams ER, Gomez MA, Scheske L, Rios R, Marquez R, Cossio A, et al. Sensitive diagnosis of cutaneous leishmaniasis by lesion swab sampling coupled to qPCR. Parasitology. 2014;141:1891-7.

45. Pessoa-e-Silva R, Mendonça Trajano-Silva LA, Lopes da Silva MA, da Cunha Gonçalves-de-Albuquerque S, de Goes TC, Silva de Morais RC, et al. Evaluation of urine for Leishmania infantum DNA detection by real-time quantitative PCR. J Microbiol Methods. 2016;131:34-41.

46. Solano-Gallego L, Rodriguez-Cortes A, Trotta M, Zampieron C, Razia L, Furlanello T, et al. Detection of Leishmania infantum DNA by fret-based realtime PCR in urine from dogs with natural clinical leishmaniosis. Vet Parasitol. 2007;147:315-9.

47. Benassi JC, Benvenga GU, Ferreira HL, Pereira VF, Keid LB, Soares R, et al. Detection of Leishmania infantum DNA in conjunctival swabs of cats by quantitative real-time PCR. Exp Parasitol. 2017;177:93-7.

48. Ceccarelli M, Galluzzi L, Sisti D, Bianchi B, Magnani M. Application of qPCR in conjunctival swab samples for the evaluation of canine leishmaniasis in borderline cases or disease relapse and correlation with clinical parameters. Parasit Vectors. 2014:7:460.

49. Carvalho Ferreira AL, Carregal VM, de Almeida FS, Leite RS, de Andrade ASR. Detection of Leishmania infantum in 4 different dog samples by real-time PCR and ITS-1 nested PCR. Diagn Microbiol Infect Dis. 2014;78:418-21.

50. Lombardo G, Pennisi MG, Lupo T, Migliazzo A, Caprì A, Solano-Gallego L. Detection of Leishmania infantum DNA by real-time PCR in canine oral and conjunctival swabs and comparison with other diagnostic techniques. Vet Parasitol. 2012:184:10-7.

51. Aschar M, de Oliveira ETB, Laurenti MD, Marcondes M, Tolezano JE, Hiramoto RM, et al. Value of the oral swab for the molecular diagnosis of dogs in different stages of infection with Leishmania infantum. Vet Parasitol. 2016;225:108-13.

52. Kassahun A, Sadlova J, Dvorak V, Kostalova T, Rohousova I, Frynta D, et al. Detection of Leishmania donovani and L. tropica in Ethiopian wild rodents. Acta Trop. 2015;145:39-44.

53. Kassahun A, Sadlova J, Benda P, Kostalova T, Warburg A, Hailu A, et al. Natural infection of bats with Leishmania in Ethiopia. Acta Trop. 2015;150:166-70.

54. de Oliveira FM, Costa LHC, de Barros TL, Rauschkolb Katsuda Ito PK, Colombo FA, de Carvalho C, et al. First detection of Leishmania spp. DNA in Brazilian bats captured strictly in urban areas. Acta Trop. 2015;150:176-81.

55. de Rezende MB, Herrera HM, Carvalho CME, Carvalho Anjos EA, Ramos CAN, de Araújo FR, et al. Detection of Leishmania spp. in bats from an area of Brazil endemic for visceral leishmaniasis. Transbound Emerg Dis. 2017;64:e36-42.

56. Ortega MV, Moreno I, Domínguez M, de la Cruz ML, Martín AB, RodríguezBertos A, et al. Application of a specific quantitative real-time PCR ( $q P C R$ ) to identify Leishmania infantum DNA in spleen, skin and hair samples of wild Leporidae. Vet Parasitol. 2017;243:92-9.

57. Muñoz-Madrid R, Belinchón-Lorenzo S, Iniesta V, Fernández-Cotrina J, Parejo JC, Serrano FJ, et al. First detection of Leishmania infantum kinetoplast DNA in hair of wild mammals: application of qPCR method to determine potential parasite reservoirs. Acta Trop. 2013;128:706-9.

58. de Almeida ME, Koru O, Steurer F, Herwaldt BL, da Silva AJ. Detection and differentiation of Leishmania spp. in clinical specimens by use of a SYBR Green-based real-time PCR assay. J Clin Microbiol. 2017;55:281-90.

59. de Paiva CM, Dantas-Torres F, da Cunha Gonçalves de Albuquerque S, Silva de Morais RC, De Brito MEF, Otranto D, et al. Quantitative real time PCR assays for the detection of Leishmania (Viannia) braziliensis in animals and humans. Mol Cell Probes. 2013;27:122-8. 
60. Manna L, Paciello O, Della Morte R, Gravino AE. Detection of Leishmania parasites in the testis of a dog affected by orchitis: case report. Parasit Vectors. 2012;5:216.

61. Molina I, Fisa R, Riera C, Falcó V, Elizalde A, Salvador F, et al. Ultrasensitive real-time PCR for the clinical management of visceral leishmaniasis in HIVinfected patients. Am J Trop Med Hyg. 2013;89:105-10.

62. da Silva RN, Amorim AC, Brandão RMSS, de Andrade HM, Yokoo M, Ribeiro $M L$, et al. Real-time PCR in clinical practice: a powerful tool for evaluating Leishmania chagasi loads in naturally infected dogs. Ann Trop Med Parasitol. 2010;104:137-43.

63. Belinchón-Lorenzo S, Iniesta V, Parejo JC, Fernández-Cotrina J, MuñozMadrid R, Soto M, et al. Detection of Leishmania infantum kinetoplast minicircle DNA by real time PCR in hair of dogs with leishmaniosis. Vet Parasitol. 2013;192:43-50

64. Geisweid K, Weber K, Sauter-Louis C, Hartmann K. Evaluation of a conjunctival swab polymerase chain reaction for the detection of Leishmania infantum in dogs in a non-endemic area. Vet J. 2013;198:187-92.

65. Pennisi MG, Reale S, Lo Giudice S, Masucci M, Caracappa S, Vitale M, et al. Real-time PCR in dogs treated for leishmaniasis with allopurinol. Vet Res Commun. 2005;29:301-3

66. Manna L, Reale S, Vitale F, Picillo E, Pavone LM, Gravino AE. Real-time PCR assay in Leishmania-infected dogs treated with meglumine antimoniate and allopurinol. Vet J. 2008;177:279-82.

67. Manna L, Reale S, Viola E, Vitale F, Manzillo VF, Michele PL, et al. Leishmania DNA load and cytokine expression levels in asymptomatic naturally infected dogs. Vet Parasitol. 2006;142:271-80.

68. Tupperwar N, Vineeth V, Rath S, Vaidya T. Development of a real-time polymerase chain reaction assay for the quantification of Leishmania species and the monitoring of systemic distribution of the pathogen. Diagn Microbiol Infect Dis. 2008;61:23-30

69. Hossain F, Ghosh P, Khan MAA, Duthie MS, Vallur AC, Picone A, et al. Realtime PCR in detection and quantitation of Leishmania donovani for the diagnosis of visceral leishmaniasis patients and the monitoring of their response to treatment. PLoS One. 2017;12:e0185606.

70. Shang L, Peng W, Jin H, Xu D, Zhong N, Wang W, et al. The prevalence of canine Leishmania infantum infection in Sichuan province, southwestern China detected by real time PCR. Parasit Vectors. 2011;4:173.

71. Toz SO, Culha G, Zeyrek FY, Ertabaklar H, Alkan MZ, Vardarlı AT, et al. A realtime ITS1-PCR based method in the diagnosis and species identification of Leishmania parasite from human and dog clinical samples in Turkey. PLoS Negl Trop Dis. 2013;7:e2205.

72. Kocher $A$, Valière $S$, Bañuls A-L, Murienne J. High-throughput sequencing of kDNA amplicons for the analysis of Leishmania minicircles and identification of neotropical species. Parasitology. 2017. https://doi.org/10.1017/ S0031182017002013.

73. Kuhls K, Alam MZ, Cupolillo E, Ferreira GEM, Mauricio IL, Oddone R, et al. Comparative microsatellite typing of New World Leishmania infantum reveals low heterogeneity among populations and its recent Old World origin. PLoS Negl Trop Dis. 2011;5:e1155.

74. Lukes J, Guilbride DL, Votýpka J, Zíková A, Benne R, Englund PT. Kinetoplast DNA network: evolution of an improbable structure. Eukaryot Cell. 2002;1: 495-502.

75. Lee ST, Tarn C, Chang KP. Characterization of the switch of kinetoplast DNA minicircle dominance during development and reversion of drug resistance in Leishmania. Mol Biochem Parasitol. 1993;58:187-203.

76. Pereira L de OR, Moreira RB, de Oliveira MP, Reis $S$ de $O$, de Oliveira Neto MP, Pirmez C. Is Leishmania (Viannia) braziliensis parasite load associated with disease pathogenesis? Int J Infect Dis. 2017;57:132-7.

77. Ceccarelli M, Galluzzi L, Diotallevi A, Gasparini E, Migliazzo A, Magnani M. The relevance of molecular diagnosis in a dog vaccinated against leishmaniasis. Vet Med Anim Sci. 2016:4:4

78. Suárez M, Valencia BM, Jara M, Alba M, Boggild AK, Dujardin J-C, et al. Quantification of Leishmania (Viannia) kinetoplast DNA in ulcers of cutaneous leishmaniasis reveals inter-site and inter-sampling variability in parasite load. PLoS Negl Trop Dis. 2015;9:e0003936.

79. Naranjo C, Fondevila D, Altet L, Francino O, Ríos J, Roura X, et al. Evaluation of the presence of Leishmania spp. by real-time PCR in the lacrimal glands of dogs with leishmaniosis. Vet J. 2012;193:168-73.

80. Francino O, Altet L, Sánchez-Robert E, Rodriguez A, Solano-Gallego L, Alberola J, et al. Advantages of real-time PCR assay for diagnosis and monitoring of canine leishmaniosis. Vet Parasitol. 2006;137:214-21.
81. Dantas-Torres F, da Silva Sales KG, Gomes da Silva L, Otranto D, Figueredo LA. Leishmania-FAST15: a rapid, sensitive and low-cost real-time PCR assay for the detection of Leishmania infantum and Leishmania braziliensis kinetoplast DNA in canine blood samples. Mol Cell Probes. 2017;31:65-9.

82. Rampazzo R de CP, Solcà M da S, Santos LCS, Pereira L de N, Guedes JCO, Veras PST, et al. A ready-to-use duplex qPCR to detect Leishmania infantum DNA in naturally infected dogs. Vet Parasitol. 2017;246:100-7.

83. Akhoundi M, Downing T, Votýpka J, Kuhls K, Lukeš J, Cannet A, et al. Leishmania infections: molecular targets and diagnosis. Mol Aspects Med. 2017:57:1-29.

84. Maroli M, Feliciangeli MD, Bichaud L, Charrel RN, Gradoni L. Phlebotomine sandflies and the spreading of leishmaniases and other diseases of public health concern. Med Vet Entomol. 2013;27:123-47.

85. Ranasinghe S, Rogers ME, Hamilton JGC, Bates PA, Maingon RDC. A real-time PCR assay to estimate Leishmania chagasi load in its natural sand fly vector Lutzomyia longipalpis. Trans R Soc Trop Med Hyg. 2008; 102:875-82.

86. Rogers ME, Bates PA. Leishmania manipulation of sand fly feeding behavior results in enhanced transmission. PLoS Pathog. 2007;3:e91.

87. González E, Álvarez A, Ruiz S, Molina R, Jiménez M. Detection of high Leishmania infantum loads in Phlebotomus perniciosus captured in the leishmaniasis focus of southwestern Madrid region (Spain) by real time PCR. Acta Trop. 2017;171:68-73.

88. Cunha RC, Andreotti R, Cominetti MC, Silva EA. Detection of Leishmania infantum in Lutzomyia longipalpis captured in Campo Grande, MS. Rev Bras Parasitol Vet. 2014;23:269-73.

89. Ayhan N, Velo E, de Lamballerie $X$, Kota M, Kadriaj P, Ozbel $Y$, et al. Detection of Leishmania infantum and a novel phlebovirus (Balkan Virus) from sand flies in Albania. Vector-Borne Zoonotic Dis. 2016;16:802-6.

90. Benabid M, Ghrab J, Rhim A, Ben-Romdhane R, Aoun K, Bouratbine A. Temporal dynamics and Leishmania infantum infection prevalence of Phlebotomus perniciosus (Diptera, Phlebotominae) in highly endemic areas of visceral leishmaniasis in Tunisia. PLoS One. 2017;12:e0184700.

91. Özbel Y, Karakuş M, Arserim SK, Kalkan \$̧O, Töz S. Molecular detection and identification of Leishmania spp. in naturally infected Phlebotomus tobbi and Sergentomyia dentata in a focus of human and canine leishmaniasis in western Turkey. Acta Trop. 2016;155:89-94.

92. Karaku SM, Pekag Irba SM, Demir S, Eren H, Toz S, Özbel Y. Molecular screening of Leishmania spp. infection and bloodmeals in sandflies from a leishmaniasis focus in southwestern Turkey. Med Vet Entomol. 2017;31:224-9.

93. Solano-Gallego L, Rossi L, Scroccaro A, Montarsi F, Caldin M, Furlanello T, et al. Detection of Leishmania infantum DNA mainly in Rhipicephalus sanguineus male ticks removed from dogs living in endemic areas of canine leishmaniosis. Parasit Vectors. 2012;5:98.

94. Dantas-Torres F, Stefania Latrofa M, Otranto D. Quantification of Leishmania infantum DNA in females, eggs and larvae of Rhipicephalus sanguineus. Parasit Vectors. 2011:4:56.

95. Viol MA, Guerrero FD, de Oliveira BCM, de Aquino MCC, Loiola SH, de Melo $\mathrm{GD}$, et al. Identification of Leishmania spp. promastigotes in the intestines, ovaries, and salivary glands of Rhipicephalus sanguineus actively infesting dogs. Parasitol Res. 2016;115:3479-84.

96. Nicolas L, Milon G, Prina E. Rapid differentiation of Old World Leishmania species by LightCycler polymerase chain reaction and melting curve analysis. J Microbiol Methods. 2002:51:295-9.

97. De Monbrison F, Mihoubi I, Picot S. Real-time PCR assay for the identification of cutaneous Leishmania parasite species in Constantine region of Algeria. Acta Trop. 2007;102:79-83.

98. Pita-Pereira D, Lins R, Oliveira MP, Lima RB, Pereira BAS, Moreira OC, et al. SYBR Green-based real-time PCR targeting kinetoplast DNA can be used to discriminate between the main etiologic agents of Brazilian cutaneous and visceral leishmaniases. Parasit Vectors. 2012;5:15

99. de Morais RCS, da Costa Oliveira CN, de Albuquerque S da CG, Mendonça Trajano Silva LA, Pessoa-e-Silva R, Alves da Cruz HL, et al. Real-time PCR for Leishmania species identification: evaluation and comparison with classical techniques. Exp Parasitol. 2016;165:43-50.

100. Selvin PR. The renaissance of fluorescence resonance energy transfer. Nat Struct Biol. 2000;7:730-4.

101. Schulz A, Mellenthin K, Schonian G, Fleischer B, Drosten C. Detection, differentiation, and quantitation of pathogenic Leishmania organisms by a fluorescence resonance energy transfer-based real-time PCR assay. J Clin Microbiol. 2003;41:1529-35. 
102. Cardoso L, Gilad M, Cortes H, Nachum-Biala Y, Lopes A, Vila-Viçosa M, et al. First report of Anaplasma platys infection in red foxes (Vulpes vulpes) and molecular detection of Ehrlichia canis and Leishmania infantum in foxes from Portugal. Parasit Vectors. 2015;8:144.

103. Migliazzo A, Vitale F, Calderone S, Puleio R, Binanti D, Abramo F. Feline leishmaniosis: a case with a high parasitic burden. Vet Dermatol. 2015;26: 69-70.

104. Opota O, Balmpouzis Z, Berutto C, Kaiser-Guignard J, Greub G, Aubert J-D, et al. Visceral leishmaniasis in a lung transplant recipient: usefulness of highly sensitive real-time polymerase chain reaction for preemptive diagnosis. Transpl Infect Dis. 2016;18:801-4.

105. White H, Potts G. Mutation scanning by high resolution melt analysis. Evaluation of RotorGene 6000 (Corbett Life Science), HR1 and 384 well LightScanner (Idaho Technology). Wessex: National Genetics Reference Laboratory; 2006.

106. de Paiva Cavalcanti M, Felinto de Brito ME, de Souza WW, de Miranda Gomes Y, Abath FGC. The development of a real-time PCR assay for the quantification of Leishmania infantum DNA in canine blood. Vet J. 2009;182: 356-8.

107. Ribeiro-Romão RP, Saavedra AF, Da-Cruz AM, Pinto EF, Moreira OC. Development of real-time PCR assays for evaluation of immune response and parasite load in golden hamster (Mesocricetus auratus) infected by Leishmania (Viannia) braziliensis. Parasit Vectors. 2016;9:361.

108. Oliveira V da C, Boechat VC, Mendes Junior AAV, Madeira M de F, Ferreira LC, Figueiredo FB, et al. Occurrence of Leishmania infantum in the central nervous system of naturally infected dogs: parasite load, viability, coinfections and histological alterations. PLoS One. 2017;12:e0175588.

109. Silva RC, Richini-Pereira VB, Kikuti M, Marson PM, Langoni H. Detection of Leishmania (L.) infantum in stray dogs by molecular techniques with sensitive species-specific primers. Vet Q. 2017;37:23-30.

110. Prina E, Roux E, Mattei $D$, Milon G. Leishmania DNA is rapidly degraded following parasite death: an analysis by microscopy and real-time PCR. Microbes Infect. 2007:9:1307-15.

111. van der Meide W, Guerra J, Schoone G, Farenhorst M, Coelho L, Faber W, et al. Comparison between quantitative nucleic acid sequence-based amplification, real-time reverse transcriptase $P C R$, and real-time PCR for quantification of Leishmania parasites. J Clin Microbiol. 2008;46:73-8.

112. Kimblin N, Peters N, Debrabant A, Secundino N, Egen J, Lawyer P, et al. Quantification of the infectious dose of Leishmania major transmitted to the skin by single sand flies. Proc Natl Acad Sci. 2008;105:10125-30.

113. Miro G, Oliva G, Cruz I, Cañavate C, Mortarino M, Vischer C, et al. Multicentric, controlled clinical study to evaluate effectiveness and safety of miltefosine and allopurinol for canine leishmaniosis. Vet Dermatol. 2009;20: 397-404.

114. Dabiri S, Safavi M, Shamsi Meymandi S, Yousefi K, Shamsi Meymandi M, Fotouhi Ardakani R, et al. Molecular pathology and histopathological findings in localized Leishmania lymphadenitis. Arch Iran Med. 2014;17:122-6.

115. Müller N, Hentrich B, Frey CF, Welle M. Quantitative PCR for the diagnosis of cutaneous leishmaniasis from formalin-fixed and paraffin-embedded skin sections. Mol Cell Probes. 2015;29:507-10.

116. Tellevik MG, Muller KE, Løkken KR, Nerland AH. Detection of a broad range of Leishmania species and determination of parasite load of infected mouse by real-time PCR targeting the arginine permease gene AAP3. Acta Trop. 2014;137:99-104.

117. Vallur AC, Duthie MS, Reinhart C, Tutterrow Y, Hamano S, Bhaskar KRH, et al. Biomarkers for intracellular pathogens: establishing tools as vaccine and therapeutic endpoints for visceral leishmaniasis. Clin Microbiol Infect. 2014 20:0374-83.

118. Colombo FA, Pereira-Chioccola VL, Meira C da S, Motoie G, Gava R, Hiramoto RM, et al. Performance of a real time PCR for leishmaniasis diagnosis using a L. (L.) infantum hypothetical protein as target in canine samples. Exp Parasitol. 2015;157:156-62.

119. Rodrigues $A C M$, Melo $L M$, Magalhães $R D$, de Moraes NB, de Souza Júnior $A D$, Bevilaqua CML. Molecular identification of Lutzomyia migonei (Diptera: Psychodidae) as a potential vector for Leishmania infantum (Kinetoplastida: Trypanosomatidae). Vet Parasitol. 2016;220:28-32.

\section{Ready to submit your research? Choose BMC and benefit from:}

- fast, convenient online submission

- thorough peer review by experienced researchers in your field

- rapid publication on acceptance

- support for research data, including large and complex data types

- gold Open Access which fosters wider collaboration and increased citations

- maximum visibility for your research: over $100 \mathrm{M}$ website views per year

At BMC, research is always in progress.

Learn more biomedcentral.com/submissions 